\title{
THE IMPACT OF THABA-BOSIU CENTRE ALTERNATIVE LIVELIHOODS PROGRAMME ON ALCOHOL PROBLEMS: A CASE STUDY OF HA MOTHAE
}

\author{
Mannini J. Masihleho ${ }^{1}$ Tankie Khalanyane*2 \\ ${ }^{1}$ Maseru, Lesotho \\ ${ }^{2}$ Institute of Southern African Studies \\ National University of Lesotho
}

\begin{abstract}
This paper is based on a study that was conducted in March 2009 aimed at assessing the impact of alternative livelihoods programme on the social and economic lives of Ha Mothae residents. A case study approach was used and a purposeful sampling technique was used in selecting respondents, while data were analyzed qualitatively. The findings indicated that the programme has benefited most of the respondents despite the problems they encountered at its implementation stage. Also that it has had relative impact on the social and economic lives of the recipients. Therefore, it is recommended that the programme should be introduced and implemented in other parts of the country to reduce the problem of alcohol dependence, and that it should be government funded.
\end{abstract}

Key Words: Alcohol dependence, alcohol problems, alternative livelihoods, case study

\section{INTRODUCTION AND BACKGROUND}

King Moshoeshoe I made the first written law prohibiting the use, importation and introduction of European brandy to Lesotho in 1854 (Molao oa yoala yoa Makhuoa, $8^{\text {th }}$ November, 1854). According to this law, disallowing the importation of the European brandy into Basutoland did not mean that traditional beer was not used because it was used for ceremonial purposes. Among the Basotho, traditional beer has always been used but was basically meant for elders, given to men while making deci- sions at khotla (local court) and used during ceremonies. For King Moshoeshoe I, the European brandy seemed to pose a more serious problem for his people than traditional beer. For example, he believed that European liquor created quarrelling and strife and that paved the way to destruction of society.

In 1870, two years after Lesotho was declared a British protectorate, King Moshoeshoe I died and his son King Letsie I took over the chieftainship. A few years later, the British administrators, missionaries and some of Basotho raised concern that the habit of drinking took a different direction. According to Mo-

Correspondence to: Tankie Khalanyane*, Senior Publications Officer, Institute of Southern African Studies, National University of Lesotho, P O Roma 180, Lesotho. Tel: (+266) 22213888/22340601; Cell: (+266) 58913474; Fax: (+266) 22340000; Email: t.khalanyane@nul.ls/tkhalanyane@yahoo.com 
hapeloa (2002:81) this habit took root during and after the Gun War - 1880-1881. He shows that before the war, the government took measures against it but because Basotho had virtually become their own masters, they consumed beer freely and the chiefs who aught to have stopped them set a bad example. One of the reasons is as stated by Sir Lagden (1909:568),

there were no efforts (laws) made to suppress brandy canteens in farms of the Free State, from which the Basotho drew supplies of this vile stuff that maddened them. In this way, King Moshoeshoe I law could not simply work.

The alcohol consumption in Lesotho then increased, leading to social problems among the Basotho. The Paris Evangelical Missionary Society (PEMS) priests were also shocked at the rate at which Basotho consumed spirituous liquor. In the words of one PEMS missionary consumption of spirituous liquor was one of the "worst aspects by which European civilization revealed itself to Basotho and abuse of spirituous liquor of European manufacture began to play havoc among them"(Duvoisin, 1967:532). What was interesting was that some of the sons of Moshoeshoe I who were chiefs and were supposed to be the custodians of his 1854 Molao oa Yoala yoa Makhuoa were the ones who were involved in the trafficking of spirituous liquor. Smith says "chiefs who had been content to buy a bottle of smuggled brandy now purchased barrels. Drunkenness was rife".

In the 1880s when drunkenness was rife among Basotho, the PEMS missionaries did not standby and watch the problem. The first attempt they did was to form and international movement in Lesotho known as Temperance Society, whose sole purpose was to campaign against liquor consumption. Recently, in the 1980s Blue-Cross Lesotho was introduced in Lesotho to deal with alcohol related problems. It is a Christian organisation which is independent of any political tendency or denominational adherence. It was founded in England and was then called HOPE UK. The objectives of the organisation were: to assist those who are battling with alcohol related problems, using every available modern means; to inform people about the dangers of alcohol and drugs; to encourage prevention amongst young people, by promoting a drug free lifestyle and to support an alcohol policy, promoting health for all.

Thaba-Bosiu Centre (TBC) was founded in 1989 to implement the objectives of BlueCross Lesotho in Lesotho. The centre operates through prevention and treatment programmes and its main objective is "to contribute towards a reduction of alcohol and drug related problems in Lesotho for individuals, families and society as a whole". The treatment programme initiatives include, treating individuals and families with alcohol and drug related problems, irrespective of religious or political affiliation. The approach was intended to pay attention to individual needs through a family and community based need. While, the objective of the prevention programme is to educate the community on alcohol and drug related problems. This entails providing education and information to specified target groups in Lesotho through the use of the media, mediating techniques, seminars, workshops, campaigns and other relevant resources available in the society.

The programme also helps people to device entrepreneurial schemes to assist them in alleviating the problems that they are experiencing related to making a living and servicing of debts. Therefore, several projects were implemented as alternative livelihoods strategies for people using alcohol and those who brew alcohol for a living. Projects undertaken were, for example, poultry farming, planting and selling of vegetables, and sewing of clothes. They were aimed at reducing the number of people brewing alcohol for commercial purposes.

Workshops and training were held for interested participants in ALPs which aimed at providing them with basic skills in engaging in the alternative livelihoods other than brewing beer. They were also being informed about the social problems associated with abuse of drugs and alcohol. 


\section{Research Issues}

The study that was undertaken at Ha Mothae from March to April 2009 was intended at assessing the impact of Alternative Livelihoods Programme that was initiated and implemented by Thaba-Bosiu Centre. The issues which the study investigated were;

- The social change in people's livelihoods,

- The economic change in people's livelihoods,

- Sustainability of the Alternative Livelihoods Programme, and

- The level of commitment to the programme by participants.

\section{METHOD}

The study was conducted at Ha Mothae village in the district of Maseru. This is where the Alternative Livelihoods Programmes were introduced and adopted by the community.

A case study approach was used in the study. "A case study is an in-depth study of a single organisation, institution, programme, event decision, policy or group which serves as the case being investigated" (Rakotsoane and Rakotsoane, 2006:18). In this study the researchers wanted to investigate the livelihoods of the community members of Ha Mothae after the alternative livelihoods programme was introduced. The study was the intrinsic case study "which is normally conducted for its own sake, in other words, to learn about this case only. There is no expectation that the results will be generalised to explain similar cases" (Sarantakos, 2005:211). According to Yin (2009:18) "A case study is an inquiry that investigates a contemporary phenomenon in depth and within its real-life context, especially when the boundaries between phenomenon and context are not clearly evident". Case studies provide descriptive and explanatory information. They also produce firsthand information in that they work in natural settings. Case studies could be qualitative or quantitative depending on whether one uses numbers or not (Rakotsoane and Rakotsoane,
2006:18). The researchers adopted the qualitative case study.

The population of this study consisted of 30 households which were involved in the programme at Ha Mothae. The sample was drawn from those people who were engaged in Alternative Livelihoods Programme. Fifteen households were selected. A non-probability sampling strategy which was purposive sampling was used. This was so because the study targeted those individuals who met the requirements for the purpose of the study by being active in the programme. According to Babbie (2004:183) "sometimes it is appropriate to select a sample on the basis of knowledge of a population, its elements and the purpose of the study".

An interview guide was developed as the data collection instrument which was divided into sections. Under participation questions, the researchers wanted to know how the informants came to be engaged in the programme, whether they volunteered or were forced to participate. With regard to questions under Alternative Livelihoods Programme, the researchers wanted to know whether there has been any economic or social change in the informants' livelihoods and whether they were committed towards the programme. The researchers wanted to find out whether the respondents were willing to continue with the programme and this was highlighted by the questions under the sustainability of the programme. Data was analysed manually by identifying the themes that emerge from findings, the patterns of variations and the relationship among responses.

\section{RESULTS}

The study aimed at assessing the impact of the Alternative Livelihoods Programme on people living at Ha Mothae, especially those who brewed beer as their main source of income. This section discusses the findings of the study about people's opinions on the impact of ALP as introduced by Thaba-Bosiu Centre (TBC) at Ha Mothae. 


\section{Demographic characteristics of the respondents}

Fifteen respondents were interviewed and two were males while the other thirteen were females. Two respondents were single, seven were married and six were widowed. With regard to the educational attainment, the highest level reached was high school. Ten respondents showed to have attained primary level, while four reached secondary and only one respondent made it to high school level. One of the reasons the respondents could not further their studies was that they could not afford further education. Among these respondents, most of them were old, that is, two respondents were in their early seventies, eight were in their late fifties and early sixties, while five were in the age range between twenty-three and forty-five years.

\section{How the respondents knew about the Alternative Livelihood Programme}

Nine respondents reported to have been informed by one of TBC representatives, through public gatherings at Ha Mothae in 2004. He was a member of the Prevention Programme at TBC. He informed Ha Mothae villagers about the problems associated with alcohol and drug abuse but specifically he was targeting those who brewed beer for commercial purposes. He made them aware of other means of living other than brewing beer which further accelerated the level of alcoholism in the country. The survival strategies he mentioned included poultry farming, piggery, planting trees, sewing and other agricultural activities.

Informants who were interested in the information disseminated by the Prevention Programme of Thaba-Bosiu Centre during public gatherings reported that they attended a workshop at Lihaseng for a week. One of the respondents said: "we undertook a said training at Lihaseng where we were taught about the Alternative Livelihoods Programme".

The other four respondents were informed by other people who had gone for training at Lihaseng while the remaining two respondents showed that they were encouraged to partici- pate in the programme by their parents who were brewers of alcohol. As one respondent reported,

"I did not go for training but I was informed by my neighbour who is a participant in the programme and I joined."

The respondents indicated that information about alternative livelihoods, which was different from brewing alcohol, seemed to be very interesting. They added that they were keen to participate, as such, they volunteered and no one forced them to participate in the programme.

\section{Reasons for participation in the programme}

There are different reasons why people decided to participate in the programme. The married and widowed respondents showed that they participated in this programme in order to support their families.

"I was not satisfied with the income I used to generate when brewing beer. With the hope that I will get a better income in this programme, I volunteered to support my family."

With regard to the two single respondents, they reported to have taken over the work of their parents and they also participate for acquisition of knowledge, that is, to know how to plant trees and make handicrafts so that they could earn a living. One of them showed that he wanted to bring a helping hand in the family as his mother was struggling to generate enough income to maintain the family. One of them reported:

"I used to be a taxi conductor, but I did not generate enough money to assist my family. I was also an alcoholic and after I received my alary, I would hook up with other colleagues at bars and drink beer. I participated in the programme because I wanted to divert from drinking alcohol." 
The other respondent indicated that he was not employed and he participated in order to generate income for the family so that all their needs could be met.

\section{Activities that were implemented in Alternative Livelihoods Programme}

There were several activities that people were informed about during their training at Lihaseng but Ha Mothae villagers chose to engage in poultry farming, sewing and tree planting because they were more affordable than other activities like selling dairy products. This meant that they would have to have livestock which they could not afford (cows, sheep and goats).

\section{Poultry Farming}

Some respondents mentioned that they engaged in poultry farming where each participant owned three hens and two cocks. They sold some eggs to generate income. As their capital, the respondents indicated that each member contributed some money to buy those chickens.

However, the respondents reported that their chickens died from sars and they had to resort to other activities to generate some income and they engaged in tree planting.

\section{Sewing}

Others used to do patchwork, sewing school uniforms, tracksuits and comforters which they had learned at the workshop. They also contributed some money to buy three sewing machines and to rent a house to work in. They indicated that TBC provided them with two extra sewing machines.

They explained that they encountered some problems in this activity, as said by one of the participants:

"We ran short of materials and could not generate some income, as a result, we resorted to tree planting hoping that we will generate income so that we can buy materials and continue with our work."
The other problem participants mentioned was lack of money, the respondents indicated that they were unable to pay for the rented house and had to take the machines to individual homes selected by participants. Some did not like this idea and showed that not all of them would access the machines when they wanted to, but, they did not have a choice because they could not afford to pay for the rented house.

\section{Tree Planting}

Currently, all the participants showed to have been planting forest trees and selling them. They indicated that they had planted 'leoka' which was in high demand by the government (Ministry of Forestry and Land Reclamation) at that time. They reported that they were hoping to generate more income and they showed that the government was the sole buyer of their produce.

Even in this activity, they reported to have encountered some problems as explained by one respondent;

"We run short of suitable soil 'selokoe' to plant more trees which we used to find along the dongas, it is not available anymore" (sic).

The other problems encountered were that, they did not have dams to draw water so that they could water the plants. The respondents also indicated that they did not have alternative market for the trees except the government so they grew old and some trees died. The respondents mentioned that this was the second year from the first sales, that their trees were not being bought. Among seven thousand trees they had planted, they managed to sell only three thousand trees to the government and they were left with four thousand trees.

The participants indicated that some of the problems arose internally, that is, within a group of participants themselves. They reported that others did not want to clean and take care of the nursery thus conflicts arose and indicated that from the overall participants, eight women quitted. 


\section{Other Activities}

The two old women aged seventy and seventy-one years respectively, showed that they no longer had strength to engage in activities which required more physical energy, as a result, they engaged in making "linthoana-nthoana" (various handicrafts). Linthoana-nthoana included using animal horns to make dishes, jewellery and frames. They also indicated that they sew mats, hats and made brooms using grass. They indicated to have learned this art at TBC during their training.

One of the two women mentioned that she was currently selling "litolobonya" (the second hand clothes) which she said were donated to them by Mazenod Mission.

\section{Opinions about the programme}

There seemed to be a variation in respondents' opinions with regard to whether they have benefited from the programme or whether there were any effects on their livelihoods since they engaged in the programme.

\section{Participants who benefited from the programme}

Generally, the respondents mentioned that they had benefited from the programme. Among the fifteen respondents, twelve of them showed to have benefited from the programme. They indicated that they now have knowledge and skills of generating income other than through brewing beer and spending their time at the bars. They indicated that with the training they had received at Lihaseng, they could make their own nurseries and sell both forest and fruit trees as their other survival strategy. They mentioned that they had learned a lot about agricultural activities since they engaged in this programme. They indicated that having the support form their families, $\mathrm{TBC}$ and their community, they have actually learned corporate skills, that is, working together for the common good and to enhance their community.

These twelve participants showed that their lives had improved since they engaged in the programme as compared to their prior survival strategies. They mentioned that the income they generated before engaging in ALP only allowed them to buy a few things but now they can afford to provide their families with their basic needs.

\section{Males who benefited}

Among these respondents, one of them showed that he was no longer dependent on alcohol as most of his time was spent in the implementation process of the Alternative Livelihoods Programme. He further showed that he engaged in sports other than going to the bars. He indicated that he could help his parents to generate more income for the family and also to meet his needs. He no longer spent his money on alcoholic beverages. The other male respondent also indicated to have acquired skills from this programme. He could supply his family with additional income. He reported to have found this programme beneficial because he was unemployed hence did not have any means of generating income.

\section{Older Participants}

One woman aged seventy-one mentioned that she was relieved from the hard work she used to do. She indicated that early in the morning she would cook steamed bread and sell at Ha Makhalanyane. Later during the day, she would continue with brewing thereby made additional income.

"Having engaged in this programme, I see a lot of improvement in my life, not only economically, but I am physically well now. I am relived form hard work because I could not even have enough rest", she reported.

For those who were also the consumers of their own product, they indicated that they do not drink beer any more.

\section{Respondents who did not benefit from the programme}

With regard to the other three respondents who indicated not to have benefited from the 
programme, they showed that they had approximately three years as participants in this programme but they did not see any progress in their livelihoods. They indicated that they participated only in tree planting and they did not have any income generated because they did not sell anything. However, they reported not to be brewing beer anymore.

\section{Changes introduced at community level after introduction of the ALP}

The participants mentioned that they spend most of their time cleaning the nursery and looking after their individual gardens and also doing domestic work as opposed to brewing or consuming alcohol. As for the two single respondents, they indicated that after their involvement in the programme, they invited their friends to participate. They even formed a soccer team at Ha Mothae with the help of the Prevention Programme. TBC supplied them with soccer equipment. These informants reported to spend most of their time at the play grounds if not at the nursery, unlike at bars like they did before.

The participants showed to had a change in their attitudes towards their survival strategies, that is, the source of their living prior to engaging in the programme. They even managed to invite other people from the village of $\mathrm{Ha}$ Rathoko to participate in the programme. They also indicated that there were no longer people who were brewing beer in the village, rather people consumed the Western-type of beer in the bars around the village and these bars were also regulated as to when they should be opened and when to be closed.

\section{Sustainability of the programme}

In corroboration with the respondents' level of satisfaction with the work they do, there seemed to be a variation in their responses with regard to their willingness to continue with these works.

Three of them were not willing to continue with the work. One of those who were not going to continue with the programme in future reasoned that it took them a long time before they could find some buyer for their products. These were mostly participants who were not engaged in any other alternative livelihoods strategies other than tree planting only.

On the other hand, those who wished to continue indicated that the skills they had acquired in this programme were essential hence why some of them brought their children to join them to keep them busy and get away from possibilities of engaging in deviant behaviours such as crime and involvement in drug and substance abuse.

This group of people thought that it was a worthwhile venture to invest in this programme and encouraged others to participate. They indicated to have done some public gatherings to inform people about the consequences of alcoholism and some preventive measures to encourage them to join.

As for the two old women, they indicated that they no longer had strength but if they are still alive, they would continue with other activities which did not require a lot of physical effort and would continue to generate some income. They mentioned that they would continue with handicrafts like making brooms and mats with grass as their way of generating income.

\section{Conclusions and Recommendations}

Based on the findings the study concluded that the Alternative Livelihoods Programme (ALP) has had a relative impact on the social and economic lives of most recipients despite the problems participants encountered in their different activities. Its major impact has been on awareness raising and education on substance abuse. Moreover, the findings indicated that people are willing to continue with the programme and this shows that Thaba-Bosiu Centre (TBC) has achieved its objectives of educating the Ha Mothae community on alcohol and drug related problems through public gatherings held in that village and through workshop and training which were held at Lihaseng. The empowerment aspect of the programme has been successful.

In addition, the study recommends that through community organisation, people can 
evaluate and solve their social problems as they identify their common problems or goals and work together to achieve these common goals. Due to the problem of alcoholism in the country that results mostly from home brewed beer, there should be adjustment of the ALP in other parts of the country to reduce the problem of alcoholism. Awareness programmes must be made about the problems of alcohol misuse in all ten districts of Lesotho.

The government should provide funds for TBC to carry/adjust the programme to other villages. The government should find market for the products of people engaging in the ALP. There should be enforcement of Liquor Licensing Act of 1997 which clearly shows the penalties of running a shebeen or bars without licences with beer brewers included. Sporting facilities should be made available for the youth to occupy them rather than spending their time in the bars and engaging in deviant behaviours like criminal activities associated with heavy drinking.

\section{REFERENCES}

Babbie, E. (2004). The practice of social research. Belmont, USA: Thomson Wadsworth.

Duvoisin, L. (1967). The shepherd and his flock. In Germond, R. C. (Ed.), Chronicles of Basutoland, a running commentary on the events of the years $1830-1902$ by French protestant Missionaries in Southern Africa (p.532). Morija: Morija Sesuto Book Depot
Mohapeloa, J. M. (2002). Tentative British Imperialism in Lesotho 1884-1910. Lesotho: Morija Museum and Archives.

Molao oa Yoala Yoa Makhuoa, $8^{\text {th }}$ November 1854, Thaba-Bosigo.

Rakotsoane, F. C. L. \& Rakotsoane, M. A, (2006). The $A B C$ of research project, dissertation and thesis proposal writing. Lesotho: Choice Publishing Company.

Sarantakos, S. (2005). Social research. New York: Palgrave Macmillan.

Sir Lagden, G. (1909). The Basutos: the mountaineers and their country. New York: Negro University Press.

Smith, E. W. (1939). The Mabilles of Basutoland. London: Hodder \& Stoughton.

Yin, R. K. (2009). Case study research design and methods. Los Angeles: Sage Publications Inc. 